\title{
Profile of Brazilian Dental Undergraduates who participated of Science Without Borders Program and their perceptions on sandwich course
}

\author{
Marina Lua Vieira de Abreu Costa*; Thais Santos Martins**; Alexandre Henrique de Melo \\ Simplicio***; Regina Ferraz Mendes****; Fabio Solon Tajra*****; Lynn Austin******* Marcoeli Silva \\ de Moura***
}

\author{
* Master student in Dentistry, Department of Pathology and \\ Dental Clinic, Federal University of Piaui \\ ** Graduated Dentist, Department of Pathology and Dental \\ Clinic, Federal University of Piaui \\ *** PhD, Professor, Department of Pathology and Dental Clinic, \\ Federal University of Piaui \\ **** PhD, Professor, Department of Restorative Dentistry, Federal \\ University of Piaui \\ ***** PhD, Professor, Department of Community Medicine, \\ Federal University of Piaui \\ ****** PhD, Professor, Department of Allied Health, Western \\ Kentucky University
}

Received June 18, 2018. Approved June 15, 2019.

\begin{abstract}
The Science without Borders (SwB) program was created in 2011 aiming to internationalizing education in Brazil and providing highly qualified training abroad. However, in 2015, it ended the offer of scholarships for undergraduates, which allowed several opportunities. The objective of this study was to evaluate the profile of Dental undergraduate students who participated in the SwB program and their perceptions about this experience. This is an evaluative research developed with students who participated in SwB in the sandwich modality, in which the student continues being enrolled in his university of origin, while studying for period in another institution abroad. Semi structured questionnaire was developed using the GoogleDocs ${ }^{\circledR}$ digital platform, addressing the sociodemographic and academic profile of participants and aspects related to the organization and operation of the program. From 745 former SwB Dental students, 109 (14.6\%) answered the questionnaire. Most of them were female (65.1\%), from public institutions $(89 \%)$, located in the Northeast $(34.9 \%)$ and Southeast $(26.6 \%)$, with proficiency in English (82.6\%), and intention to become a researcher $(51.4 \%)$. The fellows indicated that the program's objectives were partially fulfilled (59.63\%). They considered themselves more qualified, professionally, due to the sandwich course offered by SwB. However, they pointed out several limitations: lack of organization of development institutions, use of disciplines and control and inspection mechanisms. It was possible to outline the profile of program participants, as well as to characterize the functioning of SwB for Dental students, according to their perceptions.

Descriptors: Dental Education. International Educational Exchange. Higher Education.
\end{abstract}




\section{INTRODUCTION}

International student mobility is a recent phenomenon that makes it possible to develop essential knowledge, skills and attitudes to the new global economy, as well as to promote worldwide collaboration. These benefits are considered critical to continued growth and development, especially in countries that lack the capacity and infrastructure to foster national talent $^{1-2}$.

In 2011, the Brazilian government, together with its development institutions, the National Council for Scientific and Technological Development $(\mathrm{CNPq})$ and the Coordination for the Improvement of Higher Education Personnel (CAPES), launched a proposal for student mobility, of unprecedented extension and complexity in the country, pledging to provide more than 100,000 scholarships for university students between 2012 and 2015. The program was entitled Science Without Borders ( $\mathrm{SwB}$ ) and had as its main goal "to provide training and qualification of people with high qualification in universities, professional and technological education institutions and highly qualified foreign research centers in areas of priority knowledge" ${ }^{\prime 3}$.

According to CAPES data, as of April 2016, 73,353 students were awarded scholarships of sandwich course abroad. The sandwich modality occurs when the student continues to be registered at their home university, while studying for a period at other institution abroad, and after this, returns to conclude the undergraduate course. Biology, Biomedical and Health Sciences areas had $14.44 \%(n=10,595)$ of these scholars, of whom $5.8 \%(n=615)$ were Dental students sponsored by CAPES, while $\mathrm{CNPq}$ sent 130 undergraduate Dental students abroad. At the cost of almost 3 billion dollars (11 billion reais) total, the government initiative had no precedent in Brazil and found few parallels around the world ${ }^{4}$.

In this period, due to the economic and political crisis that plagued the country, the end of the offer of SwB scholarships for undergraduates was announced ${ }^{5}$. The Ministry of Education (MEC) clarified that the international scholarship program would continue to "fully function", although only in the postgraduate modalities ${ }^{6}$.

SwB was the object of criticism by Brazilian scientific societies. It is possible that the launch of the program with its huge goals and the lack of careful selection, evaluation and monitoring parameters, as well as the focus on undergraduate scholarships, may have caused a serious waste of public resources ${ }^{6}$.

This study aimed to evaluate the profile of Brazilian Dental undergraduates who participated of SwB program and their perceptions on this experience.

\section{METHODS}

\section{Study Design and Population}

This is an evaluative research project, utilizing a quantitative approach and crosssectional design, approved by the Research Ethics Committee of the Piaui Federal University (Registry 1.875.980). The research was developed with students of Dental schools in Brazil who participated in SwB Program in the modality sandwich undergraduate course in all countries and all calls/notices. According to CAPES Communication Advisory data, 615 scholarships were awarded for Dental students. $\mathrm{CNPq}$ provided a Lattes Platform link for manual access to the individual information of the fellows and, in this data collection, 130 participants from Dentistry area were located. At the $\mathrm{CNPq}$ platform, information of all participants, such as full name, institutions and e-mails, was available, while CAPES only provided the total number of grantees. The location of the other former SwB Fellows was 
carried out through the social network Facebook ${ }^{\circledR}$ in a closed group 'CsF Odontologia'. Contact was made with all former $\mathrm{CNPq}$ grantees and all 590 members of the Facebook ${ }^{\circledR}$ group within the group and individually on the participant's personal pages (chart 1).

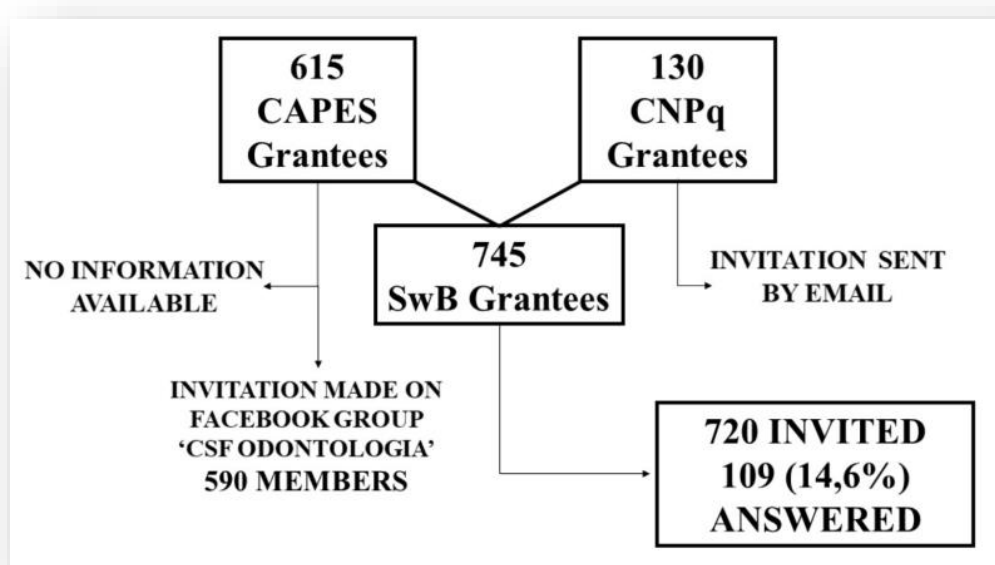

Chart 1. Study design and population

\section{Data collection}

A semi structured questionnaire was developed addressing the participant's profile (age, sex, macroregion, type of institution). Other aspects including the motivation to join the program; achievement of foreign language proficiency in Brazil and abroad; internship; taking advantage of study abroad courses in Brazil; maintaining professional contacts; assessment of the teaching and structure of institutions of destination; and, general assessment of dentistry and oral health in Brazil compared to the country of destination were also included.

The participants were questioned if they believe that the program's objectives were fulfilled. To avoid possible memory bias, the objectives set by the program organization were made available shortly after the question. At the end of the questionnaire, an open question about the weaknesses of the program was add. It is worth mentioning that the questionnaire was pre- tested with $12 \mathrm{SwB}$ participants to evaluate the comprehension of the questions and adjust the possible answers. No adjustments were necessary.

The questionnaire was applied using the GoogleDocs ${ }^{\circledR}$ digital platform. In order to send the questionnaire link, e-mails obtained on $\mathrm{CNPq}$ platform were used, all participants of the Facebook $^{\circledR}$ group were invited and the community was encouraged to spread the link through the social network WhatsApp ${ }^{\circledR}$. The social networks' use made it possible to propagate the link throughout the country.

\section{Data analysis}

Data were analyzed using the Statistical Package for Social Science (SPSS), version 20.0. The open variables were categorized to become closed for the viability of the statistical analysis. Initially, a descriptive analysis and a bivariate analysis using the Chi-square test were carried out. Independent variables for the study included 
gender, type of original institution (public or private), macro-region, participation in scientific initiation before the exchange, participation in internship, evaluation of the teaching in the institution of destination in relation to the institution of origin, evaluation of Dentistry and Oral Health in the country of destination in relation to the institution of origin to Brazil, and if the participant considers himself a professional or future professional more qualified for having participated in SwB. A significance level of $\alpha=$ $5 \%$ was established.

\section{RESULTS}

One hundred and nine (14.6\%) former SwB Fellows participated in this study (chart 1). Of the 590 contacted via Facebook, 92 (15.59\%) responded. Of 130 e-mails sent from the $\mathrm{CNPq}$ platform, 17 (13.08\%) replied.

The sociodemographic profile of the participants pointed that they were mostly female (65.1\%), 21 to 25 years old by the time of the sandwich course (69.7\%), from public institutions $(89.0 \%)$, which are in Northeast $(34.9 \%)$ and Southeast $(26.6 \%)$ of Brazil. Motivation, language proficiency and allocation were also addressed (table 1).

Academic performance before and during the exchange period was investigated through activities as scientific initiation before the exchange, courses taken on destination institution and academic training (table 2). The participants evaluated the exchange period and were questioned about their professional perspectives. Only $27.5 \%$ does not consider the idea of becoming a researcher in the future (table $3)$.

Bivariate analysis was performed, and association was found between the students' perception in relation to the fulfillment of the objectives of the SwB and their ideas about qualification after participation in the $\mathrm{SwB}$ program $(\mathrm{p}=0.018)$; and the exchange period $(\mathrm{p}$ $=0.026)($ table 4$)$.

\section{DISCUSSION}

The SwB program was launched by the Federal Government as an innovative proposal for student exchange that involved a great deal of public investment. However, there is few studies regarding the achievement of goals and the achievement of scholarship holders ${ }^{7}$. In this aspect, this quantitative study is innovative when involving Dental students who participated in this Program.

The highest proportion of SwB alumni were young women. This fact followed the trend of the feminization of the profession of Dentistry, which has been ongoing for 40 years ${ }^{8-9}$. Additionally, most participants came from institutions in the Northeast and Southeast regions. This can be explained by the fact that more than half of the Brazilian Dental Colleges are in these regions ${ }^{10}$.

When SwB was launched, the Federal Government was hopeful that a high number of undergraduates would become proficient in the language of the destination country. Many of the vacancies, however, were not filled due to lack of language fluency of the students ${ }^{11}$. Most of the participants undertook an overseas proficiency course and the predominant language was English. One of the main challenges in the development of social capital in higher education in Brazil is related to the lack of linguistic proficiency in English, which hinders the process of internationalization of education and the inclusion of the country in the globalized world $^{12}$.

The results also indicated that the main motivations of the students to join SwB were related to the desire to live abroad, with the need to learn and or become fluent in another language, investment in the future professional 
Table 1. Sociodemographic profile of Dental students participating in SwB Program in the sandwich modality and motivation to participate in the exchange between 2012 and 2016

\begin{tabular}{|c|c|c|}
\hline CATEGORY & $\mathbf{N}$ & $\%$ \\
\hline \multicolumn{3}{|l|}{ Age at the sandwich course } \\
\hline Less than 21 years old & 33 & $30.3 \%$ \\
\hline 21 to 25 years old & 76 & $69.7 \%$ \\
\hline \multicolumn{3}{|l|}{ Gender } \\
\hline Male & 38 & $34.9 \%$ \\
\hline Female & 71 & $65.1 \%$ \\
\hline \multicolumn{3}{|l|}{ Region of the Institution of Origin } \\
\hline North & 11 & $10.1 \%$ \\
\hline Northeast & 38 & $34.9 \%$ \\
\hline Midwest & 17 & $15.6 \%$ \\
\hline Southeast & 29 & $26.6 \%$ \\
\hline South & 14 & $12.8 \%$ \\
\hline \multicolumn{3}{|l|}{ Institution of Origin } \\
\hline Public & 97 & $89.0 \%$ \\
\hline Private & 12 & $11.0 \%$ \\
\hline \multicolumn{3}{|l|}{ Exchange Time } \\
\hline Up to 12 months & 60 & $55.0 \%$ \\
\hline More than 12 months & 49 & $45.0 \%$ \\
\hline \multicolumn{3}{|l|}{ Proficiency Course in Brazil } \\
\hline Yes & 75 & $68.8 \%$ \\
\hline No & 34 & $31.2 \%$ \\
\hline \multicolumn{3}{|l|}{ Proficiency Course in Brazil } \\
\hline Public & 13 & $11.9 \%$ \\
\hline Private & 62 & $56.9 \%$ \\
\hline Did not & 34 & $31.2 \%$ \\
\hline \multicolumn{3}{|l|}{ Proficiency Course Abroad } \\
\hline Yes & 83 & $76.1 \%$ \\
\hline No & 26 & $23.9 \%$ \\
\hline \multicolumn{3}{|l|}{ Which language? } \\
\hline English & 90 & $82.6 \%$ \\
\hline Spanish & 5 & $4.6 \%$ \\
\hline Italian & 10 & $9.2 \%$ \\
\hline French & 1 & $0.9 \%$ \\
\hline Dutch & 1 & $0.9 \%$ \\
\hline Other & 2 & $1.8 \%$ \\
\hline \multicolumn{3}{|c|}{ Motivation for the exchange (more than one available option) } \\
\hline Living abroad & 78 & $71.6 \%$ \\
\hline Invest in the future professional career & 54 & $49.5 \%$ \\
\hline Get to know another culture & 53 & $48.6 \%$ \\
\hline Better quality of teaching & 36 & $33.0 \%$ \\
\hline Increase independence and self-confidence & 28 & $25.7 \%$ \\
\hline Establish a network of academic relationships & 9 & $8.3 \%$ \\
\hline \multicolumn{3}{|l|}{ Country of exchange } \\
\hline USA & 56 & $51.4 \%$ \\
\hline Australia / New Zealand & 14 & $12.8 \%$ \\
\hline Italy & 10 & $9.2 \%$ \\
\hline United Kingdom & 10 & $9.2 \%$ \\
\hline Spain & 6 & $5.5 \%$ \\
\hline Canada & 4 & $3.7 \%$ \\
\hline Netherlands & 3 & $2.8 \%$ \\
\hline Germany & 2 & $1.8 \%$ \\
\hline South Korea & 1 & $0.9 \%$ \\
\hline Sweden & 1 & $0.9 \%$ \\
\hline Portugal & 1 & $0.9 \%$ \\
\hline Hungary & 1 & $0.9 \%$ \\
\hline
\end{tabular}


Table 2. Academic performance before and during the exchange period of Dental students participating in Science Without Borders Program (SwB) in the sandwich modality between 2012 and 2016

\begin{tabular}{|c|c|c|}
\hline CATEGORY & $\mathbf{N}$ & $\%$ \\
\hline \multicolumn{3}{|l|}{ Participation in scientific initiation before exchange } \\
\hline Yes & 50 & $45.9 \%$ \\
\hline No & 59 & $54.1 \%$ \\
\hline \multicolumn{3}{|l|}{$\begin{array}{l}\text { Have coursed disciplines related to the curriculum of the } \\
\text { institutions of origin during the Program? }\end{array}$} \\
\hline Yes & 89 & $81.7 \%$ \\
\hline No & 20 & $18.3 \%$ \\
\hline \multicolumn{3}{|l|}{ Use of disciplines in the institution of origin } \\
\hline Yes & 30 & $27.5 \%$ \\
\hline No & 79 & $72.5 \%$ \\
\hline \multicolumn{3}{|c|}{ Proportion of credits of courses taken abroad used by the University of origin } \\
\hline None & 78 & $71.6 \%$ \\
\hline Up to $25 \%$ & 18 & $16.5 \%$ \\
\hline Up to $50 \%$ & 7 & $6.4 \%$ \\
\hline Up to $75 \%$ & 2 & $1.8 \%$ \\
\hline From $76 \%$ to $100 \%$ & 4 & $3.7 \%$ \\
\hline \multicolumn{3}{|c|}{ Reason for not using credits (more than one available option) } \\
\hline $\begin{array}{l}\text { Disciplines already taken by the student in the Brazilian } \\
\text { High Education Institution }\end{array}$ & 62 & $56.9 \%$ \\
\hline $\begin{array}{l}\text { Disciplines that are not part of the curriculum in Brazilian } \\
\text { High Education Institution }\end{array}$ & 61 & $56.0 \%$ \\
\hline Disciplines with different format / content & 55 & $50.5 \%$ \\
\hline Unsatisfactory performance / student disapproval & 1 & $0.9 \%$ \\
\hline \multicolumn{3}{|l|}{ Academic Training } \\
\hline Yes & 79 & $72.4 \%$ \\
\hline No & 30 & $27.5 \%$ \\
\hline \multicolumn{3}{|l|}{ Place where you completed the internship } \\
\hline Internship in a teaching or research institution & 40 & $50.6 \%$ \\
\hline Internship in a private practice or clinic & 37 & $46.9 \%$ \\
\hline Internship in industry or company & 2 & $2.5 \%$ \\
\hline
\end{tabular}


Table 3. Evaluation of the exchange and professional perspectives of Dental students participating in Science Without Borders Program (SwB) in the sandwich modality between 2012 and 2016

\begin{tabular}{|c|c|c|}
\hline CATEGORY & $\mathbf{N}$ & $\%$ \\
\hline \multicolumn{3}{|c|}{$\begin{array}{l}\text { How do you consider teaching in the institution of } \\
\text { destination in relation to the institution of origin }\end{array}$} \\
\hline On the same level & 47 & $43.1 \%$ \\
\hline Better & 34 & $31.19 \%$ \\
\hline Worse & 28 & $25.69 \%$ \\
\hline \multicolumn{3}{|c|}{$\begin{array}{l}\text { How do you consider the infrastructure in the target } \\
\text { institution in relation to the home institution }\end{array}$} \\
\hline On the same level & 7 & $6.4 \%$ \\
\hline Better & 100 & $91.7 \%$ \\
\hline Worse & 2 & $1.8 \%$ \\
\hline \multicolumn{3}{|c|}{$\begin{array}{l}\text { From the re-reading of the objectives of the Program, } \\
\text { do you consider that they were fulfilled? }\end{array}$} \\
\hline Yes & 43 & $39.45 \%$ \\
\hline No & 1 & $0.92 \%$ \\
\hline In part & 65 & $59.63 \%$ \\
\hline \multicolumn{3}{|c|}{ Did you keep professional contacts abroad? } \\
\hline Yes & 68 & $62.4 \%$ \\
\hline No & 41 & $37.6 \%$ \\
\hline \multicolumn{3}{|c|}{$\begin{array}{l}\text { Did you or did you wish to enroll in a postgraduate } \\
\text { program? }\end{array}$} \\
\hline Yes & 73 & $66.9 \%$ \\
\hline No & 9 & $8.3 \%$ \\
\hline Perhaps & 27 & $24.8 \%$ \\
\hline \multicolumn{3}{|c|}{ Are you interested in becoming a researcher? } \\
\hline Yes & 56 & $51.4 \%$ \\
\hline No & 30 & $27.5 \%$ \\
\hline Perhaps & 23 & $21.1 \%$ \\
\hline \multicolumn{3}{|c|}{ Did you participate in scientific events abroad? } \\
\hline Yes & 46 & $42.2 \%$ \\
\hline No & 63 & $57.8 \%$ \\
\hline \multicolumn{3}{|c|}{$\begin{array}{l}\text { Have you been in contact with new technologies } \\
\text { (materials. instruments. techniques and equipment)? }\end{array}$} \\
\hline Yes & 95 & $87.2 \%$ \\
\hline No & 14 & $12.8 \%$ \\
\hline \multicolumn{3}{|c|}{$\begin{array}{l}\text { Do you want to go back to live and work professionally } \\
\text { abroad? }\end{array}$} \\
\hline Yes & 60 & $55.1 \%$ \\
\hline No & 6 & $5.5 \%$ \\
\hline Perhaps & 43 & $39.4 \%$ \\
\hline \multicolumn{3}{|c|}{$\begin{array}{l}\text { Do you consider yourself to be a professional or } \\
\text { qualified professional future because you have } \\
\text { participated in the SwB program? }\end{array}$} \\
\hline Yes & 101 & $92.7 \%$ \\
\hline No & 8 & $7.3 \%$ \\
\hline
\end{tabular}


Table 4. Bivariate analysis of the factors associated with the perception of Dental students participating in Science Without Borders Program (SwB) in the sandwich modality between 2012 and 2016 in relation to the fulfillment of the objectives of the SwB

\begin{tabular}{|c|c|c|c|}
\hline \multirow[t]{2}{*}{ Variable } & \multicolumn{3}{|c|}{ Compliance with SwB objectives } \\
\hline & Yes $(\%)$ & Partially (\%) & $\mathbf{P}$ \\
\hline \multicolumn{4}{|c|}{ Brazilian Macroregion } \\
\hline North & 18.2 & 81.8 & 0.354 \\
\hline Northeast & 42.1 & 57.9 & 0.162 \\
\hline Midwest & 23.5 & 76.5 & 0.737 \\
\hline Southeast & 51.7 & 48.3 & 0.069 \\
\hline South & 42.9 & 57.1 & 0.207 \\
\hline \multicolumn{4}{|l|}{ Gender } \\
\hline Female & 38.0 & 62.0 & \\
\hline Male & 42.1 & 57.9 & 0.678 \\
\hline \multicolumn{4}{|l|}{ Institution of origin } \\
\hline Public & 37.1 & 62.9 & \\
\hline Private & 58.3 & 41.7 & 0.156 \\
\hline \multicolumn{4}{|l|}{ Exchange Time } \\
\hline Up to 12 months & 30.0 & 70.0 & \\
\hline More than 12 months & 51.0 & 49.0 & 0.026 \\
\hline \multicolumn{4}{|c|}{ Participation in scientific initiation before the exchange } \\
\hline Yes & 46.0 & 54.0 & \\
\hline No & 33.9 & 66.1 & 0.198 \\
\hline \multicolumn{4}{|c|}{ Participation in internship } \\
\hline Yes & 41.8 & 58.2 & \\
\hline No & 33.3 & 66.7 & 0.421 \\
\hline \multicolumn{4}{|c|}{ Evaluation of the teaching of the institution of destination } \\
\hline On the same level & 52.9 & 47.1 & 0.156 \\
\hline Better & 32.1 & 67.9 & 0.103 \\
\hline Worse & 34.0 & 66.0 & 0.150 \\
\hline \multicolumn{4}{|c|}{$\begin{array}{l}\text { Evaluation of the Brazilian Dentistry in relation to the Dentistry of the country in which it } \\
\text { lived }\end{array}$} \\
\hline Better & 40.0 & 60.0 & 0.081 \\
\hline Worse & 64.3 & 35.7 & 0.107 \\
\hline Same level & 28.6 & 71.4 & 0.069 \\
\hline \multicolumn{4}{|c|}{ Perception of qualification after participation in the SwB program } \\
\hline Yes & 42.6 & 57.4 & \\
\hline No & 0.0 & 100.0 & 0.018* \\
\hline
\end{tabular}

career and knowledge of another culture. In fact, when analyzing the effectiveness of scholarship programs, the main benefits include expanding the understanding of other cultures, greater knowledge of content in their field of study, and learning another language ${ }^{13}$.

When conducting academic exchange, it is expected that participants will take advantage of courses at the destination institution. The percentage of achievement of subjects was 
generally nil, which was one of the worrying aspects. For the SwB undergraduates, this occurred mainly because the subjects taken abroad had already been taken by the student in the Higher Education Institution of origin, because it has a difference between the curricular structure or because they have different format/contents ${ }^{14}$.

In order to achieve the greatest success for this program and similar programs, the courses should be planned according to the needs of the territories where they are offered to meet the singularities. The greatest differences were perceived among the curricular model of Brazilian universities when compared to North American and European universities ${ }^{15}$. This compatibility must be one of the criteria for the choice of the institution of destination. However, information is lacking to ascertain whether the problem was related to the home institutions or even by each of the candidates for the scholarship.

Another item analyzed was participation in internships during the SwB program. Most of the fellows participated in internships during the exchange, only half of which were held in educational and research institutions. Many participants completed their internships in private clinics and practices, mainly as observers, and a small part in industries. Dental students were more easily able to enter stages in practices, because in many universities this modality of internship was included in the curricular matrix ${ }^{14}$. However, in most countries, the activity in the office was limited to observation because the clinical practice of the exchange students had not been authorized and the American and European institutions did not allow the care of patients by students who were not enrolled at that institution ${ }^{16}$.

Regarding survey questions pertaining to the research internship, more interest was required from the scholarship holder, since many institutions were not aware of the SwB objectives or even the program itself. Participants also reported that they did not have enough support to participate in a scientific program, according to the data which were collected in the open answers of the questionnaire. This little percentage difference between those who did research and clinical internships can be attributed to the lack of communication between the university of origin and destination, the lack of orientation services to the new social environment and of host institutions, as well as the lack of a student matching system to study the destination through a comprehensive monitoring system ${ }^{17}$.

About the quality of teaching in the institutions of destination, data revealed that, from the perception of the exchange students in relation to the institutions of origin, choices for participants were "At the same level", "Better" and "Worse". Regarding infrastructures, most of the participants reported that the institutions of destination were superior to the Brazilian ones. Since a significant minority, however, evaluated the institutions of destination as inferior to the Brazilian ones, from the analysis of $\mathrm{SwB}$ objectives, the investment is not acceptable to continue to send undergraduates to these schools ${ }^{18}$.

Some of the objectives presented by $\mathrm{SwB}$ were to increase the presence of researchers and students of various levels in institutions of excellence abroad and to promote the international insertion of Brazilian institutions by opening similar opportunities for scientists and foreign students ${ }^{3}$. It was observed that more than half of the participants are interested in becoming researchers after the program.

When questioned about the possibility of returning abroad to live or perform professionally, most participants revealed that 
they had this desire. This was not one of the identified or anticipated objectives of the program. The structure and characteristics of international government grant programs define how the program helps to promote critical benefits that help develop human capital. In addition, they can play a critical role in deciding whether the program will lead to brain drain or encourage a better distribution of science talent among countries ${ }^{17}$.

An association between the duration of the exchange and the perception of the interviewees about the fulfillment of the objectives of SwB was observed. Participants whose exchange lasted 12 months or less were more likely to consider that the program partially met the objectives. In its initial design, sandwich course would last 12 months and could be extended by up to 18 months when it included a language course. The language course term would then be presented in each call, varying from country to country and in agreement with universities abroad $^{19}$. Fellows who spent less time abroad were already proficient in the target language and did not need the language course. This influenced respondents to consider the objectives of the program as partially fulfilled, since the achievement of proficiency proved to be one of the main merits of SwB.

At the end of the questionnaire, participants were asked about the weaknesses of the program at an optional open question. Among the respondents ( $\mathrm{n}=94)$, responses were standardized in a few areas: absence of clinical practice and contact with patients, failure to take advantage of the disciplines studied abroad, lack of planning by the organizing institutions, as well as control and inspection mechanisms. For the students, these problems were the result of poor planning, which did not consider the characteristics of Dentistry teaching in Brazil, such as the prevalence of early clinical practice in undergraduate courses ${ }^{14}$.

This study had as a limitation the low rate of response, which can be explained by the nonpresence aspect of the questionnaire, the absence of official data from the scholarship holders served by CAPES and the location of possible respondents, distributed throughout the country. With the use of the digital platform GoogleDocs ${ }^{\circledR}$, the intention was to facilitate the access of the exchangers to the questionnaires and to improve the adhesion to the research.

The SwB program for society would have as short or medium term impact the internationalization of the academic production and the integration of the national research centers with the rest of the world, considering that the returned students could act as vectors in the dissemination of the knowledge acquired abroad. In the long term, the main impact would be to increase productivity and the development of human capital in the economy ${ }^{20}$. Almost all the participants in this study considered themselves professionals or future professionals more capable after the exchange.

\section{CONCLUSION}

It was possible to outline the profile of the participants of the Dentistry area in the governmental initiative SwB Program: most were female, coming from public institutions, located in the Northeast and Southeast, with proficiency in English and intentions to become a researcher. According to the participants, the program's objectives have been partially achieved. The participants considered themselves more qualified, professionally, because of the sandwich course offered by SwB. However, they pointed several weaknesses such as lack of organization of development institutions, failure to take advantage of the courses taken abroad back in the institution of origin, and the absence of control and inspection 
mechanisms.

\section{RESUMO}

Perfil dos estudantes de Odontologia brasileiros que participaram do Programa Ciência sem Fronteiras e suas percepções sobre a graduação

O programa Ciência sem Fronteiras $(\mathrm{CsF})$ foi criado em 2011 com o objetivo de internacionalizar a educação no Brasil e prover treinamento altamente qualificado no exterior. Entretanto, em 2015, encerrou a oferta de bolsas de estudo para alunos de graduação, que permitiam diversas oportunidades. $\mathrm{O}$ objetivo deste estudo foi avaliar o perfil de graduandos de Odontologia que participaram do programa $\mathrm{CsF}$ e suas percepções sobre essa experiência. Tratase de uma pesquisa avaliativa desenvolvida com estudantes que participaram do $\mathrm{CsF}$ na modalidade sanduíche, em que o estudante continua matriculado em sua universidade de origem enquanto estuda por período em outra instituição no exterior. Um questionário semiestruturado foi desenvolvido utilizando a plataforma digital GoogleDocs ${ }^{\circledR}$, abordando o perfil sociodemográfico e acadêmico dos participantes e aspectos relacionados à organização e ao funcionamento do programa. Dos 745 estudantes de Odontologia participantes do $\mathrm{CsF}, 109 \quad(14,6 \%)$ responderam ao questionário. A maioria era do sexo feminino $(65,1 \%)$, oriundos de instituições públicas (89\%), localizadas no Nordeste (34,9\%) e Sudeste $(26,6 \%)$, com proficiência em inglês $(82,6 \%)$ e intenção de se tornar pesquisador $(51,4 \%)$. Os bolsistas indicaram que os objetivos do programa foram parcialmente cumpridos $(59,63 \%)$. Consideraram-se mais qualificados, profissionalmente, devido à graduação sanduíche oferecida pelo CsF. No entanto, apontaram várias limitações: a falta de organização das instituições de fomento, de aproveitamento de disciplinas e de mecanismos de controle e inspeção. Foi possível traçar o perfil dos participantes do programa, bem como caracterizar o funcionamento do CsF para os estudantes de Odontologia, de acordo com suas percepções.
Descritores: Educação em Odontologia. Intercâmbio Educacional Internacional. Educação Superior.

\section{REFERENCES}

1. Knight J. An internationalization model: meaning, rationales, approaches, and strategies. In J. Knight, Higher Education in Turmoil: The Changing World of Internationalization. Rotterdam, The Netherlands: Sense Publishers. 2008: 19-38

2. Sehnem PR. Os programas Erasmus e Ciência sem Fronteiras como materialização da internacionalização universitária. Brazilian J Dev. 2019;5(1):533-55.

3. Brasil. Decreto n ${ }^{\circ}$ 7642, December 13, 2011. Institui o Programa Ciência Sem Fronteiras. Diário Oficial, Brasília, DF: Dec 132011.

4. Ministério da Educação. Instituto Nacional de Estudos e Pesquisas Educacionais Anísio Teixeira-INEP. Indicadores Financeiros Educacionais - INEP [Internet]. 2015 [cited 15 February, 2015]. Available from: http://portal.inep.gov.br/indicadoresfinanceiros-educacionais

5. Editorial Estadão. O fim do Ciência sem Fronteiras. O Estado de São Paulo. São Paulo, SP: September 25, 2015. [cited 25 June, 2017]. Available from: http://www.estadao.com.br/noticias/geral,ofim-do-ciencia-sem-fronteiras, 10000000076

6. Menino F. O fim do Ciência sem Fronteiras - Geral - Estadão [Internet]. Estadão. 2015 [cited 25 June, 2017]. Available from: http://www.estadao.com.br/noticias/geral,ofim-do-ciencia-sem-fronteiras, 10000000076

7. McManus C, Nobre CA. Brazilian scientific mobility program - Science without borders - Preliminary results and perspectives. An Acad Bras Cienc. 2017;89(1):773-86.

8. Morita MC, Haddad AE, Araújo ME. Perfil atual e tendências do cirurgião dentista 
brasileiro. Maringá: Dental Press, 2010. 96p.

9. McKay JC, Quiñonez CR. The Feminization of Dentistry: implications for the Profession. J Can Dent Assoc. 2012;78:c1.

10. Schmidt A, Martin S, Chisini LA, Martelli S, Morello LR. Distribuição dos cursos de Odontologia e de cirurgiões-dentistas no Brasil: uma visão do mercado de trabalho. Rev ABENO. 2018;18(1):63-73.

11. Idioma é o maior obstáculo para Ciência sem Fronteiras; inscrição vai até 24 de janeiro. UOL Educação. UOL. São Paulo, SP: January 08, 2013. [cited 25 June, 2017]. Available from: https://educacao.uol.com.br/ noticias/2013/01/04/idioma-e-o-maiorobstaculo-para-ciencia-sem-fronteirasinscricao-vai-ate-14-de-janeiro.htm

12. Finardi KR, Rojo ARO. Globalization, internationalization and education: what is the connection? Int E-Journal Adv Educ. 2015; I(1):18-25.

13. Perna LW, Orosz K, Jumakulov Z et al. Understanding the programmatic and contextual forces that influence participation in a government-sponsored international student-mobility program. High Educ. 69: 173. 2015.

14. Pithan SA, Nunes MF, Pires LC. Science without Borders in professional training: perceptions of Dental students from UFSM. Rev ABENO. 2018;18(1):2-14.

15. Fulbright. Brazilian Education System. [cited 4 Sept, 2016]. Available from: http://www.fulbright.org.br/content/view/68 197/

16. Mendonça A, Santana H. Estágio no Departamento de Odontopediatria da Universidade da Flórida: um relato de experiência. Rev ABENO. 2018;18(1):93102.

17. Grieco JA. Fostering cross-border learning and engagement through study abroad scholarships: Lessons from Brazil's Science Without Borders Program. 2015. 149. (Order No. 1604503). University of Toronto (Canada), Ann Arbor: 2015.

18. Martinez KL. Dilemas na implementação do programa Ciência sem Fronteiras: análise do perfil socioeconômico dos acadêmicos do campus da UFSC [dissertation]. Florianópolis: Universidade Federal de Santa Catarina, 2018.

19. Capes. Manual de Candidatura Programa de Graduação Sanduíche. Diretoria de Relações Internacionais - DRI, Coordenação-Geral de Bolsas e Projetos - CGBP, Coordenação de Candidaturas a Bolsas e Auxílios no Exterior - CCE. Brasília, DF: April 2015.

20. Rivas RM, Mullet S. Countervailing institutional forces that shape internationalization of science: an analysis of Brazil's Science without Borders program. RAI Rev Adm Inov. 2016;13(1):12-21.

\section{Correspondence to:}

Dr. Marcoeli Silva de Moura, PhD, e-mail: marcoeli-moura@ uol.com.br Rua Estudante Danilo Romero 1776, Horto 64.052-510, Teresina/Piaui Brazil 